Original Research Paper

\title{
Stimulating Properties of Biological Preparations on the Bulb Onion in Kazakhstan
}

\author{
${ }^{1}$ R. Zh. Ukibaev, ${ }^{2}$ N. D. Slyamova, ${ }^{3}$ G. T. Kartbaeva, ${ }^{4}$ K. L. Musaev, \\ ${ }^{1}$ G. A. Suleimanova and ${ }^{1}$ Z. B. Sapakhova \\ ${ }^{1}$ Kazakh National Agrarian Research University, Almaty, Kazakhstan \\ 2"BioPest" LLP, Almaty, Kazakhstan \\ ${ }^{3}$ Karaganda State University named after E.A. Buketov, Karaganda, Kazakhstan \\ ${ }^{4}$ Kazakh National Pedagogical University named after Abay, Almaty, Kazakhstan
}

\author{
Article history \\ Received: 09-06-2021 \\ Revised: 29-07-2021 \\ Accepted: 03-08-2021 \\ Corresponding Author: \\ R.Zh. Ukibaev, \\ Kazakh National Agrarian \\ Research University, Almaty, \\ Kazakhstan \\ Email: ukibaev87@mail.ru
}

\begin{abstract}
This article studies the stimulating properties of biological preparations Orgamica S and F used on bulb onions in Kazakhstan. As a result of our study, it has been proven that the best concentration of Orgamica $\mathrm{S}$ and $\mathrm{F}$, which significantly increases the leaf area, is a $0.4 \%$ aqueous solution. Biological preparations at a concentration of $0.4 \%$ increase the ability of onions to resist false mildew by $1.5-2$ times compared to concentrations of 0.1 and $0.2 \%$. Treatment of onions with various concentrations of Orgamica $\mathrm{S}$ and $\mathrm{F}$ solutions during the growing season reduced the damage rate of the bulbs during storage. In this variant, the biological effectiveness of the biological preparation was $91.7 \%$. With three sprayings of Orgamica S and F, both the weight of the bulbs and the yield of the bulb onions grow. The study results showed that treatment with $0.1 \%$ Orgamica $S$ and F solution allowed to increase onion yield from 1 ha to $78.1 \mathrm{t} / \mathrm{ha}$ and $68.5 \mathrm{t} / \mathrm{ha}$, respectively. The concentration of $0.4 \%$ turned out to be no less effective, since, if we consider the harvest by years, it was the processing with this concentration that gave the highest yield of the bulb onion crop in 2019. In terms of diagnostics, the preparations have a beneficial effect on reducing leaf damage.
\end{abstract}

Keywords: Onion, Onion Diseases, Biological Preparations, Resistance, Productivity, Yield

\section{Introduction}

In global vegetable growing, according to the FAO (Food and Agriculture Organization of the United Nations, 2021a, 2021b), bulb onion is the second economically important vegetable crop after tomato, both in terms of area and production. According to the classification, the bulb onion (Allium cepa L.) belongs to the family of onion plants (Alliaceae) and the onion genus (Allium), which includes more than 400 species. Only in Kazakhstan, 109 species of onions grow, including 30 endemic species, i.e., found only in this region of the globe. In 2016, 33 varieties of onions were approved for use in Kazakhstan, of which 12 varieties (36.4\%) were of Kazakh selection (selected at the Kazakh Research Institute of Potato and Vegetable Growing (KazNIIKO) (according to the website of AgroMart (2020). Currently, onion is one of the most important crops grown globally (Kumar et al., 2007) with a total sown area of about 4.4 million hectares and a production volume of 85.8 million tons. Asia makes up for $66.8 \%$ of world onion production, with China as the main producer with 22.3 million tons, followed by India with 19.3 million tons. Other major producers are the United States (3.2 million tons) and Iran (2.4 million tons). European production reaches 9.2 million tons, which corresponds to $10.8 \%$ of the total world production. Bulb onions are widely cultivated in various countries of the world and occupy about 3-5 million hectares. The sown area of this crop in Kazakhstan is about 25-28 thousand hectares. In 2016, the world areas of bulb onion amounted to 5.0 million hectares and its production reached 93.2 million tons with an average yield of 20.7 tons/ha. In Kazakhstan, bulb onions were grown in 2017 on an area of 26.7 thousand hectares, where 744.3 thousand tons of products were produced. At the same time, the main suppliers of commercial onion in Kazakhstan were the southern and southeastern regions, with the Zhambyl region producing 52.7\%, Almaty region $29.0 \%$ and South Kazakhstan region $11.1 \%$. Of 
all categories of commodity producers, individual entrepreneurs and family-owned farms occupied the bulk of production (78.4\%). In the Zhambyl region, their share was $94.3 \%$, in the Almaty region $64.7 \%$, in the South Kazakhstan region $66.6 \%$ (Committee on Statistics of the Ministry of National Economy of the Republic of Kazakhstan, 2017).

In terms of export volume to neighboring countries, especially to Russia, bulb onion ranks first among vegetable crops. Therefore, on the plantations of farmers in the southern and southeastern regions, onions are an important vegetable crop and the main livelihood of many farmers and land tenants (Amirov et al., 2018a).

Bulb onion is one of the most valuable vegetable crops for daily consumption. It is grown for green leaves and bulbs. Its value is made up of vitamins (A, B1, B2, B6, D, $\mathrm{C}$ and PP), sugars, essential oils, mineral salts of phosphorus, potassium, magnesium, titanium, zinc, iron contained in leaves and bulbs (A, B1, B2, B6, D, C and $\mathrm{PP})$. The bulbs contain many amino acids, including essential ones, which are extremely important for the metabolism in the human body, such as arginine, valine, histidine. The content of essential oils in onions determines their pungency, taste and smell. The content of essential oils ranges from 10-20 mg to 100-136 mg per $100 \mathrm{~g}$ of raw material (varietal characteristics). Bulb onion seeds also contain essential oils (20.7-24.9\% of dry weight), which have found application in medicine and perfumery. Onions are especially valued for the flavoring substances they contain, which give dishes a unique aroma and taste. Onions are widely used in canning, eaten fresh, fried and boiled, used for the preparation of salads, minced meat and in the processing industry (Lanzotti, 2006).

Interest in perennial onions has sharply increased not only because of their taste but also in connection with the active inclusion of these plants in plant breeding to obtain starting material with increased resistance to pathogenic factors (Agafonov, 1995). Despite the relatively favorable natural and climatic conditions, the production of bulb onions and shallots in Siberia does not meet the needs of the population. An important reserve for obtaining spring onion, the cultivation of perennial species, is poorly used (Grinberg et al., 1987; Grinberg, 1992). One of the serious reasons that impede the cultivation of crops is the spread of diseases (Pivovarov et al., 2001; Vorobeva, 1987; Georgieva, 2006; Glushchenko, 1981). Yield losses of onion crops from various diseases during the growing season and storage amount to at least $10 \%$ annually and in years favorable to their development up to $30-50 \%$ and more (Agafonov, 1995). Therefore, the study of the pathogenic microflora of the Allium genus is relevant both in terms of the introduction of new species and the production of long-cultivated ones. Without careful phytosanitary monitoring, it is impossible, on the one hand, to scientifically substantiate the need for protective measures and on the other hand, to use perennial species in the breeding process and introduce them into open and protected ground culture (Nikitina, 2008).

In different regions of Kazakhstan, the species composition of pathogens may differ, but everywhere economically important infectious diseases are downy mildew, or false mildew (Peronospora destructor), neck rot, Alternaria blight and Stemphylium leaf spot, root rot of sprouts caused by soil fungi of the Pythium, Rhizoctonia and Fusarium genera, pink onion root rot caused by the Phoma terrestris fungus. To increase the production and quality of onions, it is of paramount importance to improve the culture and efficiency of agriculture, the most important link of which is the protection of onions from diseases (Gawlik-Dziki et al., 2013). In winter, the range of fresh vegetables is very scarce. An important feature of bulb onions is that they are well stored and retain all their nutritional properties throughout the year.

The work aims to study the stimulating properties of biological preparations based on associative nitrogenfixing microorganisms (Orgamica S, Orgamica F) on bulb onions in the conditions of the Almaty region.

We have reviewed the protective and stimulating properties of two biological preparations, Orgamica $S$ and Orgamica F. Orgamica S and Orgamica F preparations are not yet included in the known list of biological preparations, but they can be called promising with full confidence.

\section{Materials and Methods}

In the study, the main objects were the bulb onions of the Karatal variety. Biological preparations such as Orgamica $S$ and Orgamica $F$ in various concentrations were used as growth stimulants.

Karatalskiy or Karatal (bulb onion) is a rapidly maturing and few-sprout bulb onion variety with a pungent taste. This type is unpretentious, therefore it brings a constant bountiful harvest, despite the climate and soil type. It is considered to be the best variety for storage during the winter season. The Karatal bulb onion has a rather large and rounded shape, yellowish peel and weighs only 100 to 200 grams. The Karatal bulb onion was obtained by manual selection from the already existing Johnson variety and released in 1959. This type of onion is early ripening, so the yield equals from 2 to $4.5 \mathrm{~kg}$ per sq. $\mathrm{m}$. Experts recommend growing Karatal in such territories as Uzbekistan, Armenia, Ukraine, the North Caucasus, Kyrgyzstan, the Volga region, Kazakhstan and in the Central Chernozem lands. On average, a small sample can produce half of the greenery from about mid-autumn. The grown Karatal scallion has a light green color and weak turgor, so it must be cut off in time. Since the onion is a cold-resistant plant, its seeds already begin to germinate at such a temperature as $+3-+5 \mathrm{C}$. If we talk about the growth of onions and their yield, then the most favorable temperature for this is from +18 to $+20 \mathrm{C}$. Gardeners note that the sprouts of this onion variety can withstand the first 
frosts down to $-4 \mathrm{C}$, with this description it is similar to the Centurion variety. However, it is best, because of the possible loss of yield, not to leave sprouts outdoors if a sharp drop in temperature is predicted. In such cases, onions can be covered with plastic wrap. The Turbo onion variety has about the same qualities; the description of this variety is presented here. It is known that the onion contains a huge amount of such useful substances as vitamins B1, B2, B6, niacin and folic acid and, of course, vitamin C. Onion leaves are rich in carotene. Spectral analysis revealed that Karatal ash contained more than $1 \%$ copper, aluminum and zinc and some other elements. It is advisable to use this product fresh for food, for example, for adding to salads (according to the website of Obzorteka (2021)).

Orgamica $\mathrm{S}$ is a biological fungicide based on the conidia of the Trichoderma asperellum strain (titer not less than $5 \times 10^{9} \mathrm{CFU} / \mathrm{ml}$ ). Orgamica $\mathrm{F}$ is a biological fungicide based on the spore of Bacillus amyloliguefaciens (titer not less than $\left.1 \times 10^{8} \mathrm{CFU} / \mathrm{ml}\right)$.

In the experiment, we performed the following observations and counts:

a) Observation of the growth and development of onion plants after treatment with preparations

b) Diseases were recorded by the number of diseased plants and bulbs

c) The effect of growth stimulants on the weight of the bulbs was noted

Field experiments were carried out according to the methods of B.A. Dospekhov on the land of the Shengeldy village, Almaty region. The experiment was repeated four times, the size and counting area of the plots was $0.72 \mathrm{~m}$.

The preparations were used in the following concentrations: Orgamica $\mathrm{S}$ and $\mathrm{F}$ in an $0.1,0.2,0.4 \%$ aqueous solution. Treatment in the context of the years was carried out in the period from 23 to 25 June by watering the plots. The onions were harvested in the first five days of August manually according to the following scheme: (a) Harvesting the bulbs together with the scallions and simultaneously measuring their weight by repetitions; (b) Removing the scallions and measuring the weight of the bulbs in repetitions; (c) In each repetition, the number of bulbs and leaves, including diseased ones, was counted; (d) Bulbs were laid out on a wooden floor in repetitions for storage and labeled; (e) The bulbs were dried for 2-3 weeks; (f) Dry bulbs were freed from the ground and weighed on an electronic balance; (g) According to the research data, variational series were compiled and mathematical processing was carried out on a personal computer using correlation and regression analyzes.

\section{Results}

Stimulating properties of the preparation Orgamica S.
It is known that all herbal preparations have a powerful stimulating effect, therefore the goal was set to study such terms of productivity as length, the width of the scallions and weight of bulbs. Scallion length is closely related to the width of the leaf. Considering the effect of the snare solutions on the length and width of the scallions, a regularity was revealed: The higher the concentration of the solution, the longer and wider the scallions (Fig. 1 and 2).

Based on these data, the leaf surface area was calculated using Orgamica S and F (Table 1).

From the data in Table 1, it follows that the best concentration of Orgamica $\mathrm{S}$, which significantly increases the leaf area, should be considered a $0.4 \%$ aqueous solution. Orgamica $F$ showed that when onion plants were treated with a $0.4 \%$ aqueous solution of Orgamica $\mathrm{F}$, the leaf area was maximal and amounted to $762 \mathrm{~cm}$. Variants of 0.1 and $0.2 \%$ aqueous solutions did not show much difference, although the values of leaf area in them exceed the control variant by 39 and $41 \%$, respectively.

Fungistatic properties of Orgamica S. Biological effectiveness of Orgamica $S$ was determined using the adaptability criterion. Usually, variants are compared according to development and distribution indicators or one of them. We used a pooled indicator, which is the ratio of prevalence to development, as discussed earlier. Information on the biological effectiveness of Orgamica $\mathrm{S}$ is presented in Table 4.

The data in Table 2 show that with an increase in the concentration of Orgamica S, the adaptability of the onion to disease increases. Thus, the biological effectiveness of Orgamica $\mathrm{S}$ at concentrations of $0.1 ; 0.2 ; 0.4 \%$ was respectively $73.9,87.3$ and $92.1 \%$. A biological preparation at a concentration of $0.4 \%$ increases the ability of onions to resist false mildew by $1.5-2$ times compared to concentrations of 0.1 and $0.2 \%$. In other words, the preparation has high biological effectiveness in suppressing the disease.

According to the results of the treatment with the biological preparation Orgamica $\mathrm{S}$ and Orgamica $\mathrm{F}$ against the false mildew of Karatal variety onions, the development of the disease was shown to a maximum of $8.2 \%$, while in the control variant it equaled $31.5 \%$. When using a concentration of $0.4 \%$, the development and spread of the disease were 4.2 and $4.7,86.0 \%$ lower than in the control variant. The biological effectiveness at a dose of $0.4 \%$ ranged from 92.1 to $93.0 \%$. Thus, it follows from Table 2 that with an increase in the concentration of Orgamica $\mathrm{S}$ solutions, the adaptability of the disease increases, which is proved by a curvilinear dependence (Fig. 1).

In conclusion of this section, we should dwell on the issue of increasing the resistance of bulbs to diseases during storage. Treatment of onions with various concentrations of Orgamica S and F solutions during the growing season reduced the attack rate of the bulbs during storage, which is reflected in Table 3.

According to the Table, we can conclude that the 
smallest percentage of damage to the bulbs was observed when they had been treated with $0.4 \%$ aqueous solution; the damage, in this case, amounted to $1.2 \%$. In this variant, the biological effectiveness of the biological preparation was $91.7 \%$.

According to the data of three years of studies, it was concluded that the treatment of bulb onions with solutions of Silck preparation in various concentrations affected the weight of the onion, increasing it, which is reflected in Table 4. Table 4 shows that the best concentration of the Silck preparation in increasing the weight of the bulbs is a $0.1 \%$ solution. After treatment, the average weight of one onion was $86.2 \mathrm{~g}$ on average for 3 years, which is significantly more than in the control variant.

This Table also took into account the effect of solutions on the weight of the bulbs. The total weight of the bulbs was $5623.0 \mathrm{~g}$ and $4980.0 \mathrm{~g}$ at a concentration of $0.1 \%$, while the average weight of the bulb was $86.2 \mathrm{~g}$ and $79.1 \mathrm{~g}$. After treatment with a biological preparation at a dose of $0.2 \%$, the total weight of the bulbs showed 5130.0 $\mathrm{g}$ and $4610.0 \mathrm{~g}$, respectively. Besides, when using a concentration of $0.4 \%$, the total weight was 5272.0 and $4935.0 \mathrm{~g}$, which showed high economic efficiency of $29.0 \%$.

With three sprayings of Orgamica S and F, both the weight of the bulbs and the yield of bulb onions increased (Table 5).

The research results, reflected in Table 5, show that the treatment with $0.1 \%$ solution of Orgamica $\mathrm{S}$ and $\mathrm{F}$ allowed increasing the yield of onions from 1 ha to 78.1 $\mathrm{t} / \mathrm{ha}$ and $68.5 \mathrm{t} / \mathrm{ha}$, respectively. When using a concentration of $0.2 \%$, the yield was $71.3 \mathrm{t} / \mathrm{ha}$ and 64.0 $\mathrm{t} / \mathrm{ha}$. The average bulb weight at a concentration of $0.1 \%$ was 86.2 and $79.1 \mathrm{~g}$. The concentration of $0.4 \%$ turned out to be no less effective, since, if we consider the harvest by years, it was the processing with this concentration that gave the highest yield of the bulb onion crop in 2019. The highest economic efficiency was shown after onion treatment with $0.1 \%$ Orgamica S solution $-41.7 \%$.

Table 1: Influence of the concentration of Orgamica $S$ and $F$ aqueous solutions on the leaf surface area of Karatal onions (Almaty region, 2018-2019)

\begin{tabular}{|c|c|c|c|c|c|c|c|}
\hline \multirow[b]{2}{*}{ Indicators } & \multirow[b]{2}{*}{ Control } & \multicolumn{2}{|l|}{$0.1 \%$} & \multicolumn{2}{|l|}{$0.2 \%$} & \multicolumn{2}{|l|}{$0.4 \%$} \\
\hline & & Orgamica S & Orgamica F & Orgamica $S$ & Orgamica F & Orgamica $S$ & Orgamica $F$ \\
\hline Average number of leaves, pcs. & 6.0 & 9.0 & 2.8 & 7.0 & 3.2 & 10.0 & 3.2 \\
\hline Leaf width, $\mathrm{cm}$ & 6.0 & 11.0 & 2.4 & 8.0 & 2.8 & 10.0 & 3.2 \\
\hline Leaf length, $\mathrm{cm}$ & 38.0 & 43.0 & 29.0 & 46.0 & 33.0 & 48.0 & 34 \\
\hline Leaf area, $\mathrm{cm}^{2}$ & 208.0 & 758.0 & 536.0 & 721.0 & 517.0 & $1,075.0$ & 762.0 \\
\hline
\end{tabular}

Table 2: Biological effectiveness of Orgamica S and F against false mildew of Karatal onion variety (Almaty region, 2019-2020)

\begin{tabular}{llllllll}
\hline & & $0.1 \%$ & & $0.2 \%$ & & $0.4 \%$ \\
Indicators & Control & Orgamica S & Orgamica F & Orgamica S & Orgamica F & Orgamica S & Orgamica F \\
\hline Development of the disease & 31.5 & 8.2 & 7.2 & 4.0 & 3.5 & 2.5 & 2.0 \\
Spread of the disease & 36.7 & 12.5 & 12.3 & 6.8 & 6.8 & 4.7 & 4.2 \\
$\begin{array}{l}\text { Disease Criterion (Ca) } \\
\text { Biological }\end{array}$ & 1.2 & 1.5 & 1.7 & 1.7 & 1.9 & 1.9 & 2.1 \\
effectiveness, \% & - & 73.9 & 74.8 & 87.3 & 87.7 & 92.1 & 93.0
\end{tabular}

Table 3: Influence of the concentration of Orgamica S and F on neck rot during storage (Almaty region, 2019-2020)

\begin{tabular}{|c|c|c|c|c|c|c|c|}
\hline \multirow[b]{2}{*}{ Indicators } & \multirow[b]{2}{*}{ Control } & \multicolumn{2}{|l|}{$0.1 \%$} & \multicolumn{2}{|l|}{$0.2 \%$} & \multicolumn{2}{|l|}{$0.4 \%$} \\
\hline & & Orgamica S & Orgamica $F$ & Orgamica S & Orgamica $\mathrm{F}$ & Orgamica S & Orgamica $\mathrm{F}$ \\
\hline Analyzed, pcs. & 80.0 & 80.0 & 80.0 & 80.0 & 80.0 & 80.0 & 80.0 \\
\hline $\begin{array}{l}\text { The average number of diseased } \\
\text { bulbs by type of disease, pcs. } \\
\text { The average number of diseased }\end{array}$ & 12.0 & 5.0 & 5.0 & 3.0 & 3.0 & 1.0 & 1.0 \\
\hline bulbs by type of disease, $\%$ & 15.0 & 6.2 & 5.0 & 3.7 & 2.5 & 1.2 & 1.2 \\
\hline Biological effectiveness, \% & - & 58.3 & 61.5 & 75.0 & 76.9 & 91.7 & 92.3 \\
\hline
\end{tabular}

Table 4: Influence of Orgamica S and F solutions on the weight of karatal variety bulbs (Almaty region, 2018-2019)

\begin{tabular}{|c|c|c|c|c|c|c|c|}
\hline \multirow[t]{2}{*}{ Indicators } & \multirow[b]{2}{*}{ Control } & \multicolumn{2}{|l|}{$0.1 \%$} & \multicolumn{2}{|l|}{$0.2 \%$} & \multicolumn{2}{|l|}{$0.4 \%$} \\
\hline & & Orgamica $S$ & Orgamica F & Orgamica S & Orgamica F & Orgamica S & Orgamica $\mathrm{F}$ \\
\hline Total number of bulbs, pcs. & 69.0 & 65.3 & 63.0 & 63.3 & 63.0 & 64.7 & 67.0 \\
\hline Total weight of bulbs, g. & $3,971.0$ & $5,623.0$ & $4,980.0$ & $5,130.0$ & $4,610.0$ & $5,272.0$ & $4,935.0$ \\
\hline The average weight of one bulb, g. & 67.3 & 86.2 & 79.1 & 80.9 & 72.4 & 81.3 & 74.3 \\
\hline Economic efficiency, $\%$ & - & 28.1 & 37.3 & 20.2 & 25.7 & 20.8 & 29.0 \\
\hline
\end{tabular}


R. Zh. Ukibaev et al. / OnLine Journal of Biological Sciences 2021, 21 (4): 304.311 DOI: 10.3844/ojbsci.2021.304.311

Table 5: Influence of water solutions Orgamica S and F on the yield of Karatal bulb onion variety (Almaty region, 2018-2019)

$$
0.1 \% \quad 0.2 \%
$$

\begin{tabular}{llllllll} 
Indicators & Control & Orgamica S & Orgamica F & Orgamica S & Orgamica F & Orgamica S & Orgamica F \\
\hline $\begin{array}{l}\text { Number of bulbs, pcs } \\
\begin{array}{l}\text { Average } \\
\text { bulb weight, g }\end{array}\end{array}$ & 69.0 & 65.3 & 63.0 & 63.3 & 63.0 & 64.7 & 67.0 \\
Yield, t/ha & 67.3 & 86.2 & 79.1 & 80.9 & 72.4 & 81.3 & 74.3 \\
Economic efficiency, \% & 55.1 & 78.1 & 68.5 & 71.3 & 64.0 & 73.2 & 68.5 \\
\hline
\end{tabular}

Table 6: Influence of concentrations of biological preparations on the score of damage to Karatal bulb onion variety by downy mildew (Almaty region, 2019-2020)

\begin{tabular}{llllll}
\hline Experiment variant & \multicolumn{2}{l}{ The number of leaves, pcs. } & & & \\
total & including affected & \% of affected leaves & Score of the lesion & Biological effectiveness, \% \\
\hline Control & 253 & $124-51$ & 49.0 & 2 & - \\
Orgamica S, 0.1\% & 231 & $45-80$ & 19.5 & 1 & 63.7 \\
Orgamica F, 0.1\% & 256 & $44-83$ & 17.2 & 1 & 64.5 \\
Orgamica S, 0.2\% & 242 & $30-87$ & 12.4 & 1 & 75.8 \\
Orgamica F, 0.2\% & 248 & $28-89$ & 11.3 & 1 & 77.4 \\
Orgamica S, 0.4\% & 253 & $18-93$ & 7.1 & 1 & 85.5 \\
Orgamica F, 0.4\% & 245 & $16-93$ & 6.5 & 1 & 87.1 \\
\hline
\end{tabular}

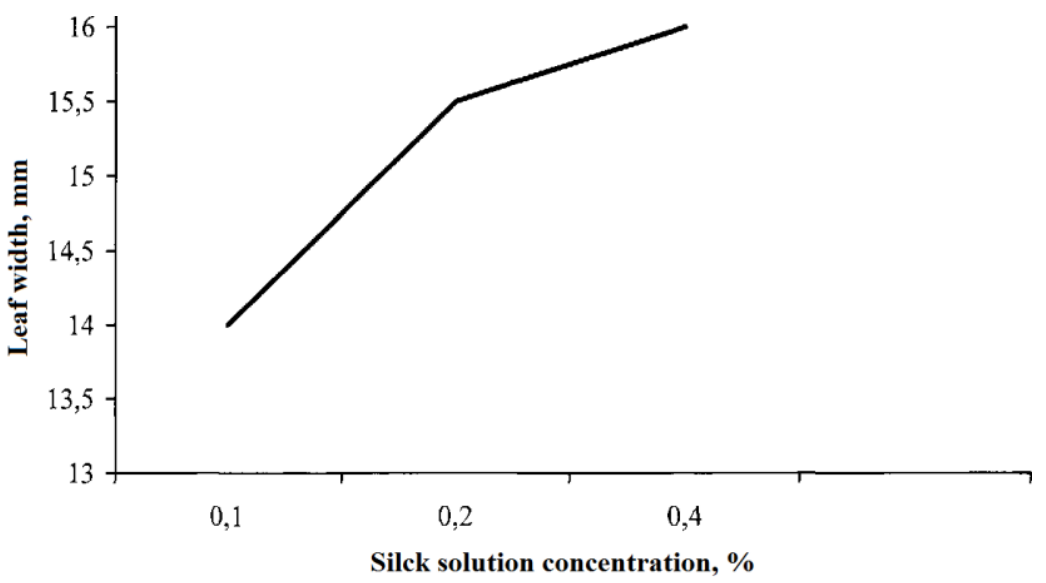

Fig. 1: Dependence of the leaf width of the Karatal variety bulb onion on the concentration of Orgamica S solutions (Almaty region, 2018-2019)

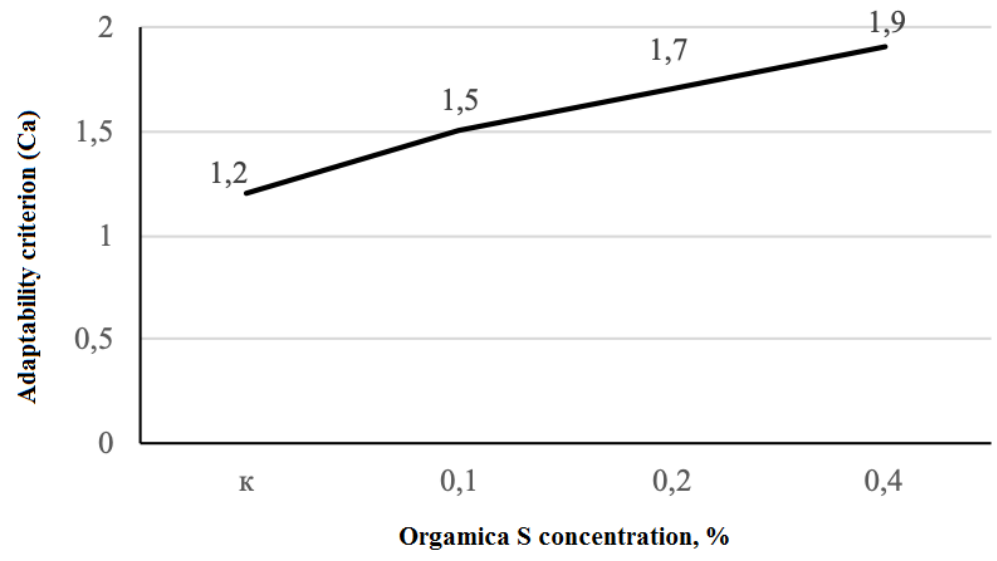

Fig. 2: Correlation between the concentration of Orgamica S and the indicator of adaptability (Almaty region, 2019-2020) 
In 2019-2020, in the Almaty region, we studied the effect of the concentration of Orgamica $S$ and Orgamica $F$ biological preparations on the assessment of the percentage of Karatal bulb onion variety affected by downy mildew (Table 6). Plant resistance to the disease was $93 \%$ at a biological preparation concentration of $0.4 \%$ and in $0.2 \%$ variants, it showed $87-89 \%$. At this concentration, this indicator was 80-83, while in the control variety $51 \%$ were resistant to this disease. At a concentration of $0.1 \%$, the leaf infestation was 19.5 and $17.2 \%$ and the biological effectiveness was 63.7 and 64.5, respectively. When using biological preparations at concentrations of $0.2 \%$, the leaf infestation was $12.4,11.3 \%$ and the biological effectiveness was 75.8 and $77.4 \%$. Thus, the results of the influence of the concentrations of biological preparations on the damage score of the Karatal onion showed that the Orgamica $\mathrm{F}$ at a concentration of $0.4 \%$ was the most effective option, with biological effectiveness of $87.1 \%$ and Orgamica $\mathrm{S}$ at a concentration of $0.4 \%$, had $7.1 \%$ of affected leaves.

It should be noted that when studying the fungistatic properties of the preparations, the main emphasis was placed on false mildew and cervical rot of the bottom. In terms of diagnostics, the preparations have a beneficial effect on reducing the damage to leaves and dramatically change the picture of the disease for the better, which ultimately affects the storage of products in the winter.

\section{Discussion}

The identity of the seven pathogenic onion fungi was confirmed at the International Institute of Mycology, Egham, London, UK. Farmer-preserved seeds from Kebbi had varying degrees of fungal infections with Fusarium spp., Aspergillus sp. and Mucor irregularis. As a result, it is recommended to pretreat onion seeds before sowing (Dauda et al., 2017). The smallest percentage of damage to the bulbs was observed when they had been treated with a $0.4 \%$ aqueous solution of Orgamica $S$ and F. According to Haile et al. (2016) downy mildew and purple spot are the main onion diseases affecting the plant during the budding stage. Infection was severe for all examined varieties and its intensity exceeded $25 \%$ in all surveyed territories Haile et al. (2016). Visual assessment, which was carried out against the background of natural disease damage, showed that 20 bulb onion samples had a very weak susceptibility to false mildew (1-10\% of leaves); 63 had a weak susceptibility (11-25\% of leaves); 91 had a medium susceptibility (26-50\% of leaves) and 118 had a strong susceptibility (more than $51 \%$ of leaves). As shown by research results, the bulb onion varieties differed significantly in productivity: The gross yield varied from 13.3 to $83.6 \mathrm{t} / \mathrm{ha}$ (Amirov et al., 2018b). In our studies, the treatment of onions with various concentrations of Orgamica $\mathrm{S}$ and $\mathrm{F}$ solutions during the growing season reduced the damage to the bulbs during storage. Nevertheless, Bimsteine et al. (2009) observed an infestation of downy mildew of about $1.6 \%$ when using chemical fungicides in hybrid lines. In studies by Abkhoo 2012, six fungicides were tested, which were sprayed three times at intervals of 10 days after the onset of symptoms. All fungicides are effective against the disease. Infinito was found to be most effective in reducing disease severity and increasing yields and also resulted in the least dead plants, the most leaves per plant and the highest number and weight of medium, large and full bulbs.

The concentration of the biological preparation Orgamica S and F at a concentration of $0.4 \%$ gave in 2019 the highest yield of the bulb onion crop in comparison with other variants and the control variant. In previous studies, when fungicides such as Acrobat Plus (dimethomorph $90 \mathrm{~g} / \mathrm{kg}$, mancozeb $600 \mathrm{~g} / \mathrm{kg}$ ), Amistar $250 \mathrm{SC}$ (azoxystrobin $250 \mathrm{~g} / \mathrm{L}$ ), Infinito SC 687.5 (fluopicolide $62.5 \mathrm{~g} / \mathrm{L}$, propamocarb HCL $625 \mathrm{~g} / \mathrm{L}$ ), Penncozeb 75 DG (mancozeb $750 \mathrm{~g} / \mathrm{kg}$ ) and Signum $33 \mathrm{WG}$ (pyraclostrobin $67 \mathrm{~g} / \mathrm{kg}$, boscalid $267 \mathrm{~g} / \mathrm{kg}$ ) were used, their spraying significantly reduced the incidence of the diseases and the biological effectiveness of fungicides averaged $74.38-89,36 \%$ and increased the yield of marketable onions by 4.3-26.3\% (Survilienè et al., 2008).

\section{Conclusion}

As a result of our study, it has been proven that the best concentration of Orgamica $\mathrm{S}$, which significantly increases the leaf area, should be considered a $0.4 \%$ aqueous solution. Orgamica $\mathrm{F}$ showed that when onion plants were treated with a $0.4 \%$ aqueous solution of Orgamica F, the leaf area was maximal and amounted to $762 \mathrm{~cm}$. Variants of 0.1 and $0.2 \%$ aqueous solutions did not show much difference, although the values of leaf area in them exceed the control variant by 39 and $41 \%$, respectively. With an increase in the concentration of Orgamica $\mathrm{S}$, the adaptability of the onion to disease increases. Thus, the biological effectiveness of Orgamica $\mathrm{S}$ at concentrations of $0.1 ; 0.2 ; 0.4 \%$ was respectively $73.9,87.3$ and $92.1 \%$. A biological preparation at a concentration of $0.4 \%$ increases the ability of onions to resist false mildew by $1.5-2$ times compared to concentrations of 0.1 and $0.2 \%$. In other words, the preparation has high biological effectiveness in suppressing the disease. Treatment of onions with various concentrations of Orgamica S and F solutions during the growing season reduced the damage rate of the bulbs during storage. The smallest percentage of damage to the bulbs was observed when treated with a $0.4 \%$ aqueous solution and amounted to $1.2 \%$. In this variant, the biological effectiveness of the biological preparation was $91.7 \%$. According to the data of three years of the study, it was concluded that the treatment of bulb onions with 
Silck solutions in various concentrations affected the weight of the onion. The best concentration of the Silck preparation in increasing the weight of the bulbs is a $0.1 \%$ solution. When treated with which the average weight of one bulb averaged 86.2 g over 3 years, which is significantly higher than in the control variant. With three sprayings of Orgamica $\mathrm{S}$ and F, both the weight of the bulbs and the yield of the bulb onions grow. Treatment with $0.1 \%$ solution of Orgamica $\mathrm{S}$ and $\mathrm{F}$ allowed increasing the yield of onion from 1 ha to 78.1 t/ha and $68.5 \mathrm{t} / \mathrm{ha}$, respectively. The concentration of $0.4 \%$ turned out to be no less effective, since, if we consider the harvest by years, it was the processing with this concentration that gave the highest yield of the bulb onion crop in 2019. In terms of diagnostics, the preparations have a beneficial effect on reducing the damage to leaves and dramatically change the picture of the disease for the better, which ultimately affects the storage of products in the winter.

\section{Author's Contributions}

All authors equally contributed in this study.

\section{Ethics}

This article is original and contains unpublished material. The authors declare that are no ethical issues and no conflict of interest that may arise after the publication of this manuscript.

\section{References}

Abkhoo, J. (2012). Efficacy of Different Fungicides for the Control of Downy Mildew of Onion. Open Access Scientific Reports, 1(133), 1-4.

Agafonov, A. F., \& Dubova, M. V. (1995). Selektsiya mnogoletnikh lukov [Breeding perennial onions]. Novye i netraditsionnye rasteniya i perspektivy ikh prakticheskogo ispolzovaniya. Tezisy dokladov pervogo mezhdunarodnogo simpoziuma [Abstracts of the first international symposium «New and nontraditional plants and prospects for their practical use»]. Pushchino, pp. 454-455.

AgroMart. (2020). Innovatsionnye sorta lukovykh kultur [Innovative varieties of onion crops]. https://agromart.kz/innovatsionnyie-sorta-lukovyih-kultur/

Amirov, B. M., Amirova, Z. S., Manabaeva, U. A., \& Zhasybaeva, K. R., (2018a). Creation and evaluation of the varietal-linear hybrids of onion in Kazakhstan. Breeding and seed production of agricultural crops, 4(42), 6-10.

Amirov, B. M., Amirova, Zh. S., Manabaeva, U. A., \& Zhasybaeva, K. R. (2018b). Sozdanie i otsenka sortolineinykh gibridov luka repchatogo v Kazakhstane [Creation and evaluation of cultivar bulb onion hybrids in Kazakhstan]. Ovoshchi Rossii, 4, 6-10. https://doi.org/10.18619/2072-9146-2018-4-6-10
Bimsteine, G., Lepse, L., \& Bankina, B. (2009). Possibilities of integrated management of onion downy mildew. Scientific works of the Lithuanian institute of horticulture and Lithuanian university of agriculture. sodininkystė ir daržininkystè, 28(3), 11-17. http://www.1sdi.lt/straipsniai/28-3/4_Lepse.pdf

Committee on Statistics of Ministry of National Economy of the Republic of Kazakhstan. (2017). 3 Seriya. Selskoe, lesnoe i rybnoe khozyaistvo. Valovoi sbor selskokhozyaistvennykh kultur v Respublike Kazakhstan za 2017 god [Series 3. Agriculture, forestry and fisheries. Gross harvest of agricultural crops in the Republic of Kazakhstan for 2017]. Astana.

Dauda, W.P., Alao, S. E. L., Zarafi, A. B., \& Alabi, O. (2017). Detection and identification of seed borne fungi on farmer saved seeds of onions (allium cepa) in kebbi state, northwest Nigeria. MAYFEB Journal of Agricultural Science, 3, 18-24.

https://mayfeb.com/index.php/AGR/article/view/101

Food and Agriculture Organization of the United Nations. (2021a). Onion. http://www.fao.org/landwater/databases-and-software/cropinformation/onion/en/ (accessed on May 23, 2021)

Food and Agriculture Organization of the United Nations. (2021b). Crops.

Gawlik-Dziki, U., Świeca, M., Dziki, D., Baraniak, B., Tomiło, J., \& Czyż, J. (2013). Quality and antioxidant properties of breads enriched with dry onion (Allium cepa L.) skin. Food Chem., 138, 1621-1628. https://doi.org/10.1016/j.foodchem.2012.09.151

Georgieva, O. (2006). Otbor luka repchatogo na ustoichivost $\mathrm{k}$ sheikovoi gnili Botrytis sp. Innovatsionnye tekhnologii $\mathrm{v}$ selektsii i semenovodstve selskokhozyaistvennykh kultur [Bulb onion selection for the resistance to neck rot caused by Botrytis sp. Innovative technologies in breeding and seed production of agricultural crops]. Materials of an international research and practice conference. Moscow, pp. 69-70.

Glushchenko, V. I. (1981). Novoe v diagnostike i morfologii vozbuditelya peronosporoza luka [New in the diagnosis and morphology of the causative agent of onion false mildew]. Mikologiya i fitopatologiya, 15(5), 405-409.

Greenberg, E. G., Grankina, V. P., Klimova, A. I., \& Suzan, V. G. (1987). Perennial bows. Novosib book publishing house, Novosibirsk.

Grinberg, E. G., Koshnikovich, V. I., \& Oksenenko, V. I. (1992). Root crops, onions. Novosib book publishing house, Novosibirsk.

Haile, B., Babege, T., \& Hailu, A. (2016). Diseases and Insect Pests of Onion (Allium cepa L.) in Masha District of Sheka Zone, South-West Ethiopia. Academia Journal of Agricultural Research, 4(10), 629-632.

https://www.academiapublishing.org/journals/ajar/p df/2016/Oct/Haile\%20et\%20al.pdf 
Kumar, R. D., Kamra, N., Agarwal, N., \& Chaudhary, L. C. (2007). In vitro methanogenesis and fermentation of feeds containing oil seed cakes with rumen liquor of buffalo. Asian-Aust. J. Anim. Sci., 20(8), 1196-1200. https://doi.org/10.5713/ajas.2007.1196

Lanzotti, V. (2006). The analysis of onion and garlic. Journal of Chromatography A, 1112, 3-22. https://doi.org/10.1016/j.chroma.2005.12.016

Nikitina, S. M. (2008). Patogennye mikromitsety i optimizatsiya fitosanitarnogo sostoyaniya luka $\mathrm{v}$ lesostepi Priobya. [Pathogenic micromycetes and optimization of the phytosanitary state of onions in the forest-steppe of the $\mathrm{Ob}$ region], $\mathrm{Ph} . \mathrm{D}$. thesis. Kinel.

Obzorteka. (2021). Karatal onion variety description. https://obzorteka.ru/ogorod/luk-karatalskij-opisaniesorta.html
Pivovarov, V. F., Ershov, I. I., \& Agafonov, A. F. (2001). Lukovye kultury [Onion crops]. Gos. Nauch uchrezhdenie VNIISSOK, Moscow.

Survilienė, E., Valiuškaite, A., \& Raudonis, L. (2008). The effect of fungicides on the development of downy mildew of onions. Zemdirbyste-Agriculture, 95(3), 171-179.

http://193.219.178.8/tomai/95(3)tomas/95(3)tomas_ 171_179.pdf

Vorobeva, A. A. (1987). Formy luka kak iskhodnyi material dlya selektsii na ustoichivost $\mathrm{k}$ lozhnoi muchnistoi rose. Selektsiya ovoshchnykh kultur [Onion forms as a starting material for breeding for downy mildew resistance. Vegetable breeding]. Sb. nauch. tr. VNIISSOK [A collection of research papers published in VNIISSOK]. Moscow, pp. 73-81. 